\title{
вмJ Global Health Mitigating gender-based violence risk in the context of COVID-19: lessons from humanitarian crises
}

\author{
Vandana Sharma (D) , ${ }^{1,2}$ Emily Ausubel, ${ }^{2}$ Christine Heckman, ${ }^{3}$ Erin Patrick, ${ }^{4}$ \\ Dimple Save, ${ }^{5}$ Jocelyn T D Kelly (1) ${ }^{2,6}$
}

\begin{abstract}
To cite: Sharma V, Ausubel E, Heckman C, et al. Mitigating gender-based violence risk in the context of COVID-19: lessons from humanitarian crises. BMJ Global Health 2021;6:e005448. doi:10.1136/ bmjgh-2021-005448
\end{abstract}

Received 19 February 2021 Accepted 24 February 2021

Check for updates

C Author(s) (or their employer(s)) 2021. Re-use permitted under CC BY-NC. No commercial re-use. See rights and permissions. Published by BMJ.

${ }^{1}$ Department of Global Health and Population, Harvard University T H Chan School of Public Health, Boston, Massachusetts, USA

${ }^{2}$ Harvard Humanitarian Initiative, Cambridge, Massachusetts, USA ${ }^{3}$ UNICEF, New York City, New York, USA

${ }^{4}$ CARE, Atlanta, Georgia, USA ${ }^{5}$ Action Against Hunger, Juba, South Sudan

${ }^{6}$ Brigham and Women's Hospital Boston, Massachusetts, USA

Correspondence to Dr Vandana Sharma; vsharma@hsph.harvard.edu
The COVID-19 pandemic is directing muchneeded attention to gender-based violence (GBV) worldwide and is particularly shining a light on the hidden epidemic of intimate partner violence (IPV). In recent months, there has been a plethora of high-profile statements calling for measures to address the GBV 'shadow pandemic'. ${ }^{1}$ For example, a joint statement by $146 \mathrm{UN}$ member states and observers declared support for the UN Secretary General's appeal to prioritise prevention and redress of violence against women in national COVID-19 response plans. ${ }^{23}$ This is an important opportunity to translate attention to action.

Much of the advocacy on GBV in the context of COVID-19 has focused on two areas: strengthening response services for GBV survivors and enhancing prevention efforts targeting root causes of violence. ${ }^{145}$ However, the third pillar of action for addressing GBVGBV risk mitigation-is also crucial. GBV risk mitigation interventions aim to reduce exposure to GBV and ensure that humanitarian response actions and services themselves do not cause harm or increase risk of violence. ${ }^{6}$ This approach also seeks to proactively identify and reduce the risks of violence related to humanitarian programming. ${ }^{6}$

There is consensus in the humanitarian sector that GBV risk mitigation is a collective responsibility and should be systematically integrated in the design, implementation and evaluation of actions to respond to disasters and emergencies. ${ }^{6}$ Unfortunately, during the COVID-19 pandemic, this has often been overlooked. Public health measures implemented to curb the spread of the virus have augmented the risk of IPV across the globe. ${ }^{17}$ Stay-at-home orders and quarantine measures have increased GBV survivors' exposure to violent partners, limited their options for seeking safety and reduced access to and
Summary box

Public health measures to curb the spread of COVID-19 have contributed to increased risk of gender-based violence (GBV) globally.

- The third pillar of action for addressing GBV, GBV risk mitigation, is crucial alongside GBV response and prevention efforts to effectively address GBV in the context of COVID-19.

- GBV risk mitigation interventions aim to reduce exposure to GBV and ensure that humanitarian response actions and services themselves do not cause harm or increase risk of violence.

- Good practices, lessons and evidence on GBV risk mitigation in humanitarian contexts have been generated over the last three decades, and there is clear and practical guidance available including guidance tailored for COVID-19.

- It is critical that local and national governments and other responders in COVID-19 affected countries incorporate GBV risk mitigation approaches into their public health measures to reduce the spread of COVID-19 to ensure these efforts do not continue to increase risk of GBV.

availability of critical GBV, health and psychosocial services. UNFPA estimates that, globally, every 3 months of lockdown contributes an additional 15 million cases of GBV. ${ }^{8}$

Clear and practical guidance on GBV risk mitigation is available in the humanitarian sphere through the Inter-Agency Standing Committee Guidelines for Integrating Gender-Based Violence Interventions in Humanitarian Action (GBV Guidelines). ${ }^{6}$ These guidelines provide recommendations across a range of sectors-including education, food security, nutrition and healthon how to analyse and address GBV risks in the design, implementation and evaluation of humanitarian programming. Well-placed lighting, for instance, can help women feel safe while using communal latrines at night thereby increasing access to and use of water, 
sanitation and hygiene facilities, ${ }^{9}$ which helps reduce the risk of infectious diseases. ${ }^{10}$ However, because such lighting can also increase the presence of men and boys in these locations and raise GBV risks, handheld lanterns may sometimes be a better risk mitigation option. ${ }^{9}$ This illustrates the need for careful consideration of potential unintended consequences of programming and the need for continuous consultation with women and girls. It also highlights how GBV risk mitigation, when properly implemented, can contribute to improved uptake and potential effectiveness of humanitarian interventions.

Good practices, lessons and evidence on GBV risk mitigation generated over the last three decades continue to be valuable tools in the current context. However, COVID-19 brings new challenges. Some effective GBV risk mitigation strategies may require adaptation to the evolving realities on the ground. For example, limitations on gathering sizes may hinder in-person focus group discussions with women and girls; consultations may thus need to be delivered through other modalities. In South Sudan, Action Against Hunger (ACF) is currently conducting consultations in smaller groups while maintaining social distancing. Additionally, good practices such as safety audits, as well as ensuring operational feedback mechanisms and at least one female staff member per nutrition facility continue to be implemented by ACF. GBV risk mitigation guidance tailored to COVID-19 is now available on behalf of the GBV Guidelines Reference Group, but more learning is needed. ${ }^{11}$

Though additional work is required to fully adapt standard risk mitigation measures from humanitarian response to fit the COVID-19 context, good practices for GBV mitigation in emergencies are also now applicable well beyond 'traditional' humanitarian settings as the world grapples with this unprecedented global crisis. It is crucial that first responders, local and national governments, national disaster management agencies and social service providers in COVID-19 affected countries systematically incorporate GBV risk analysis and mitigation strategies into their COVID-19 interventions.

Conducting gender and risk analyses of response efforts is a key first step. Consultations with women and girls and groups at increased risk (eg, persons with disabilities) must be prioritised despite operational challenges in the face of COVID-19 restrictions. Existing guidance can help safely navigate such issues. ${ }^{11}{ }^{12}$ In addition, women's organisations have context-specific expertise and deep understanding of women's and girls' specific risks and needs. These organisations should be engaged in a meaningful way at all stages of response efforts. Unintended consequences of COVID-19 response efforts must be considered, measured and addressed to ensure response actions are not causing harm or increasing risk of violence. Finally, GBV has consistently been underfunded, accounting for only $0.12 \%$ of humanitarian aid between 2016 and 2017; additional resources are necessary. ${ }^{13}$ Longer term actions include advancing research on GBV risks and mitigation interventions, assessing their effectiveness and committing to mainstreaming GBV risk mitigation within institutional policies, procedures and programmes.

Integrating GBV risk mitigation into COVID-19 response measures, alongside strengthened GBV prevention and response, is critical to effectively addressing this double pandemic. The global community must back up commitments with investment and action to improve the safety and well-being of women and girls now and in future crises.

Twitter Vandana Sharma @VSharmaGlobHth and Jocelyn T D Kelly @jtdkelly

Contributors VS and JTDK have been leading research on good practices to monitor and evaluate GBV risk mitigation interventions in emergencies. EP is the Global Inter-agency GBV Guidelines Coordinator and based at CARE. CH is a GBV in Emergencies Specialist at UNICEF. DS is the Head of Nutrition at Action Against Hunger in South Sudan. EA has conducted research on GBV and protection and supported GBV and emergency response programming. VS and EA wrote the initial manuscript draft. CH, EP, DS and JTDK provided critical input and edits. All authors read and approved the final manuscript.

Funding This work was funded by the government of the USA.

Competing interests We declare no competing interests.

Patient consent for publication Not required.

Provenance and peer review Not commissioned; internally peer reviewed. Data availability statement There are no data in this work.

Open access This is an open access article distributed in accordance with the Creative Commons Attribution Non Commercial (CC BY-NC 4.0) license, which permits others to distribute, remix, adapt, build upon this work non-commercially, and license their derivative works on different terms, provided the original work is properly cited, appropriate credit is given, any changes made indicated, and the use is non-commercial. See: http://creativecommons.org/licenses/by-nc/4.0/.

\section{ORCID iDs}

Vandana Sharma http://orcid.org/0000-0002-4156-0229

Jocelyn T D Kelly http://orcid.org/0000-0002-4603-2046

\section{REFERENCES}

1 UN Women. Violence against women and girls: the shadow pandemic, 2020. Available: https://www.unwomen.org/en/news/ stories/2020/4/statement-ed-phumzile-violence-against-womenduring-pandemic [Accessed 8 Aug 2020].

2 United Nations Secretary General. Secretary-General's video message on gender-based violence and COVID-19, 2020. Available: https://www.un.org/sg/en/content/sg/statement/2020-04-05/ secretary-generals-video-message-gender-based-violence-andcovid-19-scroll-down-for-french [Accessed 8 Aug 2020].

3 UN Member States and Observers. Answering the UN SecretaryGeneral's Call on Gender-Based Violence and COVID-19 - Statement by 146 UN Member States and Observers. Available: https://www. mfat.govt.nz/en/media-and-resources/news/joint-united-nationsstatement-on-gender-based-violence-under-covid-19/ [Accessed 8 Aug 2020].

4 UN Women. Interagency statement on violence against women and girls in the context of COVID-19, 2020. Available: https://www. unwomen.org/en/news/stories/2020/6/statement-inter-agencystatement-on-violence-against-women-and-girls-in-the-context-ofcovid-19 [Accessed 8 Aug 2020]

5 Rollston R, Wilkinson E, Abouelazm R, et al. Comprehensive sexuality education to address gender-based violence. Lancet 2020;396:148-50.

6 InterAgency Standing Committee (IASC). Guidelines for integrating GBV interventions in humanitarian action, 2015. Available: https:// gbvguidelines.org/wp/wp-content/uploads/2016/10/2015_IASC_ Gender-based_Violence_Guidelines_full-res.pdf [Accessed 8 Aug 2020].

7 van Gelder N, Peterman A, Potts A, et al. COVID-19: reducing the risk of infection might increase the risk of intimate partner violence. EClinicalMedicine 2020;21:100348. 
8 UNFPA. Impact of the COVID-19 pandemic on family planning and ending gender-based violence, female genital mutilation and child marriage, 2020. Available: https://www.unfpa.org/resources/impactcovid-19-pandemic-family-planning-and-ending-gender-basedviolence-female-genital [Accessed 8 Aug 2020].

9 Oxfam, Loughborough University. Shining a light: how lighting in or around sanitation facilities affects the risk of gender-based violence in camps; 2018.

10 Freeman MC, Garn JV, Sclar GD, et al. The impact of sanitation on infectious disease and nutritional status: a systematic review and meta-analysis. Int J Hyg Environ Health 2017;220:928-49.

11 GBV Guidelines Reference Group. Identifying \& Mitigating Genderbased Violence Risks within the COVID-19 Response. GBV
Guidelines Reference Group, 2020. Available: https://gbvguidelines. org/wp/wp-content/uploads/2020/04/Interagency-GBV-riskmitigation-and-Covid-tipsheet.pdf [Accessed 8 Aug 2020].

12 UN Women \& World Health Organization (WHO). Violence against women and girls data collection during COVID-19, 2020. Available: https://www.who.int/reproductivehealth/publications/violence/jointprogramme-on-vaw-data/en/ [Accessed 8 Aug 2020].

13 International Rescue Committee (IRC) and Voice. Where is the money? how the humanitarian system is failing in its commitments to end violence against women and girls. Available: https://www. rescue.org/report/wheres-money-how-humanitarian-system-failingfund-end-violence-against-women-and-girls [Accessed 8 Aug 2020]. 